\title{
BANTUAN HUKUM YANG IDEAL BAGI MASYARAKAT TIDAK MAMPU
}

\section{IDEAL LEGAL AID FOR THE POOR SOCIETY}

\section{Dadang Supriyatna}

\author{
Fakultas Hukum Universitas Djuanda Bogor \\ Jl. Tol Ciawi No. 1, Kotak Pos 35, Bogor 16720. \\ Korespondensi : Dadang Supriyatna, Telp. - \\ e-mail : dadang.supriyatna@unida.ac.id
}

\begin{abstract}
Jurnal Living Law, Vol. 10, No. 1 , 2018

hlm. 11-22

Abstract : This study analyzes the importance of the position of advocates in the legal system in Indonesia. Advocates have a very important role in law enforcement. The defense for all people, including the community, is a manifestation of an advocate's respect for the principle of equality before the law as well as the realization of the rights of all people, namely the right to be accompanied by an advocate. The purpose of the research is to (1) find out the position and role of advocates in the implementation of human rights in Indonesia, (2) Analyze the barriers of advocates in realizing their position and role. The research method used is qualitative and normative juridical ap-proach, namely law is conceived as a norm, rule, principle or dogmas / juris- prudence. The normative juridical research phase uses literature studies. The results of the study indicate that Advocates have a very important position and role as one of the elements of the Preacher's Legal Chess, because of the status of free and independent advocates guaranteed by law and regulation, For the sake of legal interests and demands for professions that have social aspects, every the person involved in the case has the right and guaranteed access to legal assistance. Other results indicate factors that prevent advocates from realizing their position and role related to the normative level, namely the absence of specific legal aid arrangements that regulate the entire scope of the provision of legal assistance.
\end{abstract}

Keywords : Legal Aid, advocate, Poor Society.

\begin{abstract}
Abstrak : Penelitian ini menganalisis tentang pentingnya kedudukan advokat dalam sistem hukum di Indonesia. Advokat memiliki peranan yang sangat penting dalam penengakan hukum. Pembelaan bagi semua orang termasuk masyarakat merupakan wujud penghayatan advokat ter- hadap prinsip persamaan kedudukan di hadapan hukum sekaligus perwu- judan hak yang dimiliki semua orang yaitu hak untuk didampingi advokat. Tujuan peneltian adalah untuk (1) mengetahui kedudukan dan peranan advokat dalam pelaksanaan hak asasi manusia di Indonesia, (2) Menga- nalisis faktor-faktor penghambat advokat dalam mewujudkan kedudukan dan peranannya. Metode penelitian yang digunakan adalah kualitatif dan pendekatan yuridis normatif, yaitu hukum dikonsepsikan sebagai norma, kaidah, asas atau dogma-dogma/ yurisprudensi. Tahap penelitian yuridis normatif, menggunakan studi literatur. Hasil Penelitian menunjukkan bahwa Advokat mempunyai kedudukan dan peranan yang sangat pent- ing sebagai salah satu unsur dari Catur Wangsa Penengak Hukum, karena status advokat bebas dan mandiri yang dijamin oleh hukum dan peratur- an perundang-undangan, Demi kepentingan hukum dan tuntutan profe- si yang memiliki aspek sosial, setiap orang yang terlibat perkara berhak dan terjamin tersedianya akses untuk mendapatkan bantuan hukum. Hasil lain menunjukkan faktor yang menghambat advokat dalam mewujudkan kedudukan dan peranannya terkait dengan tataran normatif, yakni belum adanya pengaturan tentang bantuan hukum secara khusus yang mengatur seluruh ruang lingkup tentang pemberian bantuan hukum.
\end{abstract}

Kata Kunci : Bantuan Hukum, Advokat, Masyarakat Tidak Mampu. 


\section{PENDAHULUAN}

Lebih kurang satu setengah abad lalu profesi advokat secara formal telah diakui keberadaannya dalam proses peradilan di Indonesia atau sama usianya dengan Land Raad, lembaga peradilan yang didirikan pemerintah Kolonial Belanda untuk golongan pribumi berdasarkan Staatblad 1847 Nomor 23 yang berlaku tanggal 1 Mei 1848. Namun pengakuan keberadaan profesi advokat tidak diatur secara khusus dan sistimatis dalam peraturan setingkat undang-undang. Tetapi hanya tertuang secara sporadis pada pasal-pasal peraturan perundang-undangan yang dikeluarkan sejak masa pemerintah Kolonial Belanda sampai masa kemerdekaan. ${ }^{1}$

Setelah runtuhnya kekuasaan rezim Orde Baru lahirlah sebuah era baru yaitu era reformasi dimana dengan sejumlah agenda penting yang mempunyai tekad merubah dan membangun kembali segala aspek tatanan kehidupan bangsa ini dari suasana kekuasaan otoriter menjadi lebih demokratis. Salah satu agenda penting tersebut adalah reformasi di bidang hukum. Reformasi di bidang hukum, telah melahirkan berbagai perubahan yang diawali amandemen konstitusi, UndangUndang Dasar 1945 yang akan menjadi jiwa dan pedoman utama bagi lahirnya peraturan selanjutnya.

Salah satu peraturan perundangundangan yang lahir setelah amandemen Undang-Undang Dasar 1945 adalah Undang-Undang Nomor 18 Tahun 2003 tenang Advokat. Walaupun Undang-undang Advokat ini mengalami proses pembahasan cukup panjang sejak rancangan undangundang disampaikan ke Dewan Perwakilan Rakyat (DPR) tanggal 28 September 2000 sampai akhirnya disahkan menjadi sebuah undang-undang pada tanggal 6 Maret 2003, namun masih saja dinilai mengandung banyak kelemahan. Bahkan undang-undang ini ditenggarai sarat dibebani oleh berbagai

\footnotetext{
1 Yudha Pandu. "Klien dan Advokat Dalam Praktek", PT.Aba di, Jakarta, 2005, hlm.1
}

kepentingan, sehingga banyak kalangan merasa pesimis dan bertanya sinis, apakah Undang-undang Advokat dapat merubah keadaan profesi advokat kepada keadaan yang lebih baik. ${ }^{2}$

Meskipun demikian, dalam situasi yang penuh pesimisme dan sinisme masyarakat, lahirnya Undang-undang Advokat ini merupakan lompatan besar dalam sejarah profesi advokat di Indonesia. Berdasarkan undang-undang ini profesi advokat diakui sebagai penegak hukum sejajar dengan profesi hukum lain, seperti halnya : Polisi, Jaksa dan Hakim, sehingga masih ada harapan dan optimisme untuk dijadikan modal dalam membangun kembali moral dan integritas profesi advokat yang telah lama menjadi puing-puing keadilan dan kebenaran.

Advokat dalam praktek hukum di Indonesia adalah orang yang mewakili kliennya untuk melakukan tindakan hukum berdasarkan surat kuasa yang diberikan untuk pembelaan atau penuntutan pada acara persidangan di pengadilan (litigator), sedang konsultan hukum adalah orang yang bekerja di luar pengadilan yang bertindak memberikan nasehat-nasehat dan pendapat hukum terhadap suatu tindakan/perbuatan hukum yang akan dan telah dilakukan kliennya (non litigator), namun advokat selain menjalankan praktek di pengadilan, dapat juga mendampingi atau mewakili seorang klien di luar pengadilan berdasarkan surat kuasa atau order yang diberikan kepadanya (non litigation).

Hak Hukum adalah hak setiap orang, tidak hanya untuk masyarakat yang ekonominya rendah tetapi termasuk masyarakat yang ekonominya menengah keatas (mampu), karena merupakan hak asasi manusia yang dijamin dalam Universal Declaration of Human Rights. ${ }^{3}$

Hak Hukum merupakan hak warga negara, Indonesia sebagai negara hukum telah menjamin warganya sama kedudukannya di muka hukum, sebagaima-

\footnotetext{
2 Ibid, hlm.6-7.

${ }^{3}$ Ibid, hlm 9-10
} 
na diatur dalam Pasal 27 ayat (1) UndangUndang Dasar 1945.4

Peraturan Pemerintah yang mengatur tentang kewajiban advokat untuk memberikan bantuan hukum kepada masyarakat hingga sekarang juga belum ditetapkan. ${ }^{5}$ Padahal Undang-undang Advokat pada Pasal 22 ayat (1 dan 2) telah mengatur dengan tegas menetapkan ${ }^{6}$ :

1. Advokat wajib memberikan bantuan hukum secara cuma-cuma kepada pencari keadilan yang tidak mampu.

2. Ketentuan mengenai persyaratan dan tata cara pemberian bantuan hukum secara cuma-cuma sebagaimana dimaksud pada ayat (1).

Perhimpunan Advokat Indonesia telah mewajibkan anggotanya untuk memberikan bantuan hukum pada masyarakat. Mereka yang melanggar akan diberi sanksi. Hal ini dikemukakan oleh Ketua Umum Perhimpunan Advokat Indonesia, Otto Hasibuan juga menyatakan, kewajiban memberikan bantuan hukum ini akan menjadi prioritas utama organisasi. Dikatakan pula, selama ini kegagalan organisasi profesi advokat dalam memberikan bantuan hukum karena tidak ada ketentuan yang mewajibkan advokat untuk memberi bantuan hukum, sehingga sifatnya hanya sukarela. "Ini juga salah satu faktor yang menyebabkan advokat jauh dari masyarakat," paparnya. ${ }^{7}$

Ditambah lagi dalam Pasal 34 ayat (1) Undang-undang Dasar 1945 pengakuan hak sipil, politik, ekonomi, sosial, dan budaya dari fakir miskin, yang berarti adanya pengakuan terhadap hak untuk dibela oleh advokat atau pembela umum bagi fakir miskin, maka undang-undang bantuan hukum mutlak diperlukan dalam

\footnotetext{
4 Bintan R. Saragih. "Perubahan, Penggantian dan Penetapan Undang-Undang Dasar di Indonesia", CV. Utomo, Bandung, 2006, hlm. 182

5 Ibid.

6 Undang-Undang Nomor 18 Tahun 2003 tentang Advokat, Citra Umbara, Bandung, 2003, hlm. 15.

7 Otto Hasibuan. "Advokat Yang Tidak Memberikan Bantu an Hukum Akan Diberikan Sanksi, Pidato dalam Deklarasi PERADI", Jakarta, tanggal 23 Desember 2004.
}

rangka mempertegas hak untuk memperoleh bantuan hukum bagi fakir miskin.

Atas dasar pertimbangan tersebut, fakir miskin memiliki hak untuk diwakili dan dibela oleh advokat baik di dalam maupun di luar pengadilan (legal aid) sama seperti orang mampu yang mendapatkan jasa hukum dari advokat (legal service). Penegasan sebagaimana diambil dari Pasal 34 ayat (1) Undang-undang Dasar 1945 memberikan implikasi bahwa bantuan hukum bagi fakir miskin pun merupakan tugas dan tanggung jawab negara dan merupakan Hak Konstitusional ${ }^{8}$ yang juga merupakan bagian Hak Asasi Manusia di hadapan hukum.

Sebagaimana telah diuraikan sebelumnya perangkat hukum positif yang ada kurang memadai untuk menunjang konsep bantuan hukum sebagai hak konstitusional. Oleh karena itu bantuan hukum perlu dijabarkan lebih lanjut di dalam undang-undang bantuan hukum yang memuat konsep, fungsi, dan sifat dari bantuan hukum. Konsep bantuan hukum dalam Undang-Undang Dasar 1945 telah dinyatakan secara jelas dan tegas, agar hak konstitusional rakyat untuk memperoleh bantuan hukum dapat terjamin' .

Berdasarkan uraian di atas menunjukan bahwa sebenarnya peranan advokat dalam hak asasi manusia sangatlah memegang peranan penting. Sungguhpun demikian terkait dengan persoalan akademis, maka bantuan hukum bagi masyarakat tidak mampu secara teoritis konsepsional dan eksistensinya secara konstitusional masih perlu dijustifikasi oleh suatu undang-undang, dalam hal ini undang-undang tentang Bantuan Hukum. Selama bantuan hukum belum diatur dalam suatu undang-undang maka eksistensi bantuan hukum belum mendapatkan kepastian hukum, karena kepastian hukum itu merupakan produk dari hukum atau lebih khusus dari perundang-undangan,

\footnotetext{
${ }^{8}$ Ibid.

${ }^{9}$ Ibid.
} 
begitu datang hukum atau undang-undang maka datanglah kepastian.

\section{B. Permasalahan}

1. Bagaimanakah kedudukan dan peranan advokat dalam pelaksanaan hak asasi manusia di Indonesia?

2. Faktor apakah yang menjadi penghambat advokat dalam mewujudkan kedudukan dan peranannya?

\section{Landasan Pemikiran}

Hak asasi manusia secara definitif merupakan unsur normatif yang berfungsi sebagai pedoman berprilaku, melindungi kebebasan, kekebalan serta menjamin adanya peluang bagi setiap individu dalam menjaga harkat dan martabatnya yang meliputi unsur pemilikan dan penerapannya, paling tidak ada dua teori, yaitu pemberian hak adalah untuk dilakukan, dimiliki, dinikmati dan merupakan kesatuan dari klaim yang absah (keuntungan didapat dari pelaksanaan hak yang disertai pelaksanaan kewajiban) ${ }^{10}$.

Secara harfiah hak asasi manusia ialah hak yang dimiliki oleh seseorang karena orang itu adalah manusia. Hak asasi manusia bersifat universal dengan kata lain hak asasi dimiliki oleh seluruh umat manusia secara universal.

Jan Materson dari Komisi Hak Asasi Manusia Perserikatan Bangsa-Bangsa mengemukakan bahwa yang dimaksud dengan hak asasi manusia ialah hak-hak yang melekat pada diri manusia dimana apabila hak ini tidak dimiliki oleh manusia, maka mustahil ia dapat hidup sebagai manusia. Pernyataan ini memiliki makna yang luas atau kompleks sehingga tidak menutup kemungkinan adanya hak-hak yang dimiliki manusia belum tercantum dalam definisi hak asasi manusia, menurut Deklarasi Universal tentang Hak Asasi Manusia yang diumumkan Perserikatan Bangsa-Bangsa pada tahun 1948 yang

10 Dede Rosyada, dkk. "Pendidikan Kewargaan (CivicEduca tion) : Demokrasi Hak Asasi Manusia dan Masyarakat Madani", ICCE UIN Syarif Hidayatullah Prenada Media, Jakarta, 2000, hlm. 199-120. menyebutkan bahwa hak asasi manusia adalah hak dasar seluruh umat manusia.

Hak Asasi Manusia adalah hak-hak yang langsung diberikan oleh Tuhan Yang Maha Pencipta (hak-hak bersifat kodrat). Oleh karenanya tidak ada kekuasaan apapun di dunia ini yang dapat mencabutnya. Namun demikian tidak berarti bahwa hak tersebut manusia dapat berbuat menurut kehendaknya, karena ia harus menghormati hak-hak manusia lainnya. Hak asasi manusia terdiri atas dua hak yang fundamental yaitu hak persamaan dan hak kebebasan.

Menurut Peter R. Baehr, yang dimaksud dengan hak asasi manusia adalah hak dasar yang dipandang mutlak perlu bagi perkembangan individu. Manusia sebagai makhluk mengetahui bahwa tanpa adanya hak asasi yang secara individu harus ada, tidak mungkin manusia dapat membangun sebuah masyarakat yang beradab ${ }^{11}$. Masyarakat beradab adalah masyarakat yang dalam kehidupannya selalu mengedepankan, menghormati, dan menghargai nilai-nilai kemanusiaan baik secara individual maupun secara kelompok.

Berdasarkan Undang-Undang Nomor 39 Tahun 1999 tentang Hak Asasi Manusia, dijelaskan bahwa hak asasi manusia adalah seperangkat hak yang melekat pada hakikat keberadaan manusia sebagai makhluk Tuhan Yang Maha Esa, dan merupakan anugerah-Nya yang wajib dihormati, dijunjung tinggi, dan dilindungi oleh negara, hukum, pemerintah, dan setiap orang demi kehormatan serta perlindungan harkat dan martabat manusia. ${ }^{12}$ Hak asasi manusia disini juga termasuk hak atas persamaan dihadapan hukum (equlity before the law), semua masyarakat tanpa dibeda-bedakan berhak atas perlindungan hukum dan berhak

11 H. Djaali. dkk. "Hak Asasi Manusia (Suatu Tinjauan Teoritis dan Aplikasi)", CV. Restu Agung, Jakarta, 2003, hlm.3-4

12 Sentosa Sembiring. "Himpunan PerundangUndangan Re- publik Indonesia Tentang Hak Asasi Manusia",CV.Nuansa Aulia, Bandung, 2006, hlm.13. 
mendapatkan bantuan hukum dari advokat.

Sedangkan arti negara hukum menurut B. Hestu Cipto Handoyo B., bahwa : Pada hakikatnya berakar dari konsep kedaulatan hukum yang pada prinsipnya menyatakan bahwa kekuasaan di dalam suatu negara adalah hukum, oleh sebab itu seluruh alat perlengkapan negara apapun namanya termasuk warga negara harus tunduk dan patuh serta menjunjung tinggi hukum tanpa kecuali.

Konsep negara hukum menghendaki adanya unsur-unsur dalam penyelenggaraan sistem ketatanegaraan, yaitu: ${ }^{13}$

1. Adanya jaminan terhadap hak asasi manusia

Unsur jaminan terhadap hak asasi manusia merupakan unsur yang pertama, negara terbentuk kare- na adanya kontrak sosial. Dari kontrak sosial inilah individuindividu dalam ikatan kehidupan bersama dalam negara menyerahkan hak-hak politik dan sosialnya kepada ikatan komunitas negara. Oleh karena hak-hak tersebut diserahkan kepada negara, maka negara harus memberikan jaminan kepada hakhak baik yang melekat di dalam individu maupun hak-hak di dalam kehidupan kemasyarakatan dalam memperoleh perlindungan atau bantuan hukum.

2. Adanya pembagian kekuasaan

Untuk melindungi hak asasi manusia, kekuasaan di dalam negara harus dibagibagi ke dalam organ negara. Kekuasaan negara dibagi-bagi antara kekuasaan untuk menyelenggarakan pemerintahan (eksekutif), kekuasaan untuk membentuk undang-undang (legislatif), dan kekuasaan untuk melaksanakan peradilan (yudikatif).

3. Adanya asas legalitas pemerintahan

Pemerintahan dalam melaksanakan tugas dan tanggung jawabnya harus berdasarkan atas hukum atau ketentuan perundang-undangan yang berlaku.

\footnotetext{
13 Handoyo Cipto Hestu. B. "Hukum Tata Negara, Kewargane- garaan dan Hak Asasi Manusia", Universitas Atmajaya, Yogya karta, 2003, hlm. 12.
}

4. Adanya prinsip peradilan yang bebas dan tidak memihak

Supremasi hukum yang ditegakkan dalam kehidupan ketatanegaraan harus benar-benar dijamin pelaksanaannya. Peradilan yang bebas dan tidak memihak tidak semata-mata diletakkan dalam konteks kebebasan dari lembaga peradilan, melainkan harus diletakkan dalam konteks proses peradilan (due process law) dan dalam rangka penegakan hukum (law enforcement). Dengan demikian dalam mekanisme proses peradilan yang harus bebas dan tidak memihak menyangkut organ-organ penegak hukum seperti Hakim, Jaksa, Polisi dan Advokat haruslah dapat menjunjung tinggi nilai-nilai hak asasi manusia, bahwa manusia mempunyai kedudukan yang sama dihadapan hukum tanpa kecuali.

Dalam negara hukum (rechtsstaat) negara mengakui adanya perlindungan hak asasi manusia untuk setiap individu. Pengakuan negara terhadap hak individu pada teorinya tersirat di dalam persamaan kedudukan di hadapan hukum bagi semua orang. Dalam suatu negara hukum semua orang harus diperlakukan sama di hadapan hukum (equality before thelaw). Persamaan di hadapan hukum harus diimbangi juga dengan persamaan perlakuan (equal treatment). Perolehan pembelaan dari seorang advokat atau pembela umum (access to legal counsel) adalah hak asasi manusia setiap orang dan merupakan salah satu unsur untuk memperoleh keadilan (access to justice) bagi semua orang (justice for all). Tidak ada seorang pun dalam negara hukum yang diabaikan haknya untuk memperoleh bantuan hukum dari seorang advokat dengan tidak memperhatikan latar belakangnya, seperti agama, keturunan, ras, etnis, keyakinan politik, strata sosioekonomi, warna kulit dan gender. ${ }^{14}$

\footnotetext{
14 Frans H. Winarta. "Dasar Konstitusional Bantuan Hukum", http://jodisantoso.blogspot. com June 16,
} 2007. 
Dalam perkembangannya sekarang, konsep bantuan hukum kini dihubungkan dengan cita-cita negara kesejahteraan (welfarestate), sehingga hampir setiap pemerintah dewasa ini memberi bantuan hukum sebagai bagian dari program, serta fasilitas kesejahteraan dan keadilan sosial ${ }^{15}$, disini pemerintah telah melaksanakan kewajiban untuk memberikan kesejahteraan kepada rakyatnya dalam hal bantuan hukum. Teori konsep negara hukum yang berkembang ke arah konsep negara kesejahteraan (welfarestate) adalah negara tidak hanya menjaga ketertiban dan keamanan atau sekedar penjaga malam (nachtwakerstaat), melainkan negara turut serta dalam usahausaha sosial ${ }^{16}$ dalam hal ini program bantuan hukum sebagai pelaksanaan hak asasi manusia.

\section{METODE PENELITIAN}

Pendekatan penelitian yang digunakan dalam penelitian ini adalah kualitatif dan pendekatan yuridis normatif, yaitu hukum dikonsepsikan sebagai norma, kaidah, asas atau dogma-dogma/ yurisprudensi. Tahap penelitian yuridis normatif, menggunakan studi literatur.

\section{PEMBAHASAN}

\section{KEDUDUKAN DAN PERANAN ADVOKAT.}

Idealnya profesi advokat senantiasa membela kepentingan rakyat tanpa membeda-bedakan latar belakang agama, budaya, warna kulit, tempat tinggal, tingkat ekonomi, gender, dan lain sebagainya. Pembelaan bagi semua orang termasuk fakir miskin merupakan wujud penghayatan advokat terhadap prinsip persamaan kedudukan di hadapan hukum sekaligus perwujudan hak yang dimiliki semua orang yaitu hak untuk didampingi advokat yang

\footnotetext{
15 Adnan Buyung Nasution. "Bantuan Hukum di Indonesia", LP3ES, Jakarta, 1982, hlm. 4.

16 Ellydar Chaidir. "Negara Hukum, Demokrasi dan Konstala- si Ketatanegaraan Indonesia", Kreasi Total Media, Yogyakarta, 2007, hlm. 40.
}

didasari oleh tanggung jawab moral dan pertimbangan kemanusiaan; kondisi ekonomi, yang juga dilandasi alasan demi kepentingan hukum, yaitu pandangan bahwa setiap orang yang terlibat suatu perkara berhak untuk mendapatkan bantuan hukum sebagaimana ditentukan oleh peraturan perundang-undangan yang berlaku, yang juga didasari oleh tuntutan profesi yang memang memiliki aspek sosial, yakni ikut menjamin tersedianya akses setiap masyarakat untuk mendapatkan bantuan hukum, serta tuntutan profesi untuk tidak membedabedakan klien yang diwakili.

Tingkat keterlibatan advokat di Indonesia cukup tinggi dalam pelaksanaan bantuan hukum (pro bono publico). Malah sedikit yang mengatakan belum pernah memberikan bantuan hukum pro bono publico, rata-rata lebih disebabkan oleh hambatan eksternal ketimbang ketiadaan komitmen pribadi untuk melaksanakannya.

Tingginya keterlibatan advokat secara kuantitatif dalam aktivitas pro bono publico tersebut tidak dengan sendirinya menjadi indikasi bahwa pelaksanaan bantuan hukum di Indonesia telah berjalan dengan baik. Kenyataannya hanya sedikit advokat yang mendasarkan kegiatannya tersebut pada tujuannya yang lebih besar, bahwa prinsip fair trial harus terus dijaga sejalan dengan amanat ketentuan perundang-undangan serta nilai-nilai profesi yang menuntut mereka untuk menjamin akses masyarakat menuju proses peradilan formal tanpa membeda-bedakan golongan masyarakat yang diwakili. Lebih sedikit lagi, advokat yang melembagakan kegiatan bantuan hukumnya secara berkelanjutan melalui lembaga-lembaga bantuan hukum, atau melalui organisasiorganisasi advokat.

Bantuan hukum yang didasarkan pada pertimbangan kemanusiaan cenderung bersifat instan (sekali selesai), tidak terprogram karena sangat dipengaruhi oleh hubungan psiko-sosial yang timbul antara pemberi dan penerima yang bersifat insidental, serta tidak membidik tujuan 
tertentu utamanya supremasi hukum dan keadilan sosial yang bersifat lebih luas. Sedangkan bantuan hukum yang dilatari alasan demi kepentingan hukum, atas tuntutan profesi, dan dilakukan secara kelembagaan melalui institusi-institusi yang relevan akan lebih berkelanjutan karena telah diagendakan untuk diperjuangkan secara konsisten, guna mencapai tujuan yang lebih besar selain pencapaian keadilan individual.

Apabila sebagian besar advokat di Indonesia memandang bantuan hukum sebagai sebuah "amal profesi" belaka, bisa dimengerti mengapa pelembagaan bantuan hukum berjalan sedemikian tersendat dan tidak kunjung direalisasikan sebagai gerakan kolektif. Jika cara pandang tersebut terus digunakan, tan- pa diiringi upaya mentransformasikannya sebagai komitmen perjuangan dari identitas bersama akan berimplikasi langsung pada:

a. Senjangnya distribusi kesempatan,

b. Miskinnya akan kualitas bantuan hukum karena dilakukan tanpa landasan idealisme yang memadai,

c. Semakin menjauhnya posisi advokat dari penerimaaan serta dukungan publik.

Soal penting lainnya dalam konteks pengakuan atas status dan kedudukan dan peranan advokat adalah masalah kewajiban. Pada dasarnya kewajiban advokat merupakan kewajiban profesi yang bersifat otonom. Gagasan yang mendasarinya adalah bahwa profesi advokat merupakan profesi yang bebas. Konsekuensinya profesi advokat memiliki suatu standar nilai dan norma yang dilahirkan dan diterapkan dari kalangan profesi itu sendiri. Dengan demikian, kewajiban pokok yang berkaitan dengan profesinya ditetapkan oleh komunitas (organisasi) profesi, yaitu tanggung jawab profesi hukum yang sering dibahasakan secara umum sebagai kode etik profesi.

Disamping adanya kewajiban yang tercakup dalam tanggung jawab profesi hukum yang bersifat otonom, advokat juga dikenal kewajiban tertentu oleh negara. Hal ini didasarkan pada kedudukannya yang tidak terlepas dari sistem penegakkan hukum dalam negara. Dengan dasar ini, negara perlu memberikan pengaturan dalam batas-batas tertentu untuk menjamin bahwa sistem penegakkan hukum akan dapat berjalan dengan baik.

Salah satu kewajiban pokok advokat sebagai pemberi bantuan hukum di lingkungan peradilan adalah pemenuhan kualifikasi dasar agar dapat berinteraksi secara fungsional dengan pelaku peradilan lainnya, dan menjamin terselenggaranya proses peradilan yang mengedepankan prinsip sederhana, murah dan cepat. Tanpa adanya standar kualifikasi misalnya, dapat terjadi situasi di mana advokat yang beracara di pengadilan tidak memiliki pengetahuan yang cukup mengenai hukum acara dan substansi hukum kasus yang disidangkan sehingga terjadi kekacauan dalam peradilan kasus tersebut.

Dasar pemikiran dari perlunya kualifikasi tertentu bagi advokat adalah karakteristik utama dari profesi yaitu adanya pengetahuan dan keterampilan yang mendalam. Keduanya kemudian dilembagakan dalam ukuran kemampuan kualitas yang sama bagi semua orang melalui penentuan kualifikasi. Tanpa adanya kualifikasi ini, maka pembedaan antara masyarakat umum dengan masyarakat profesi yang berhak atas hakhak dan diserahi tanggung jawab profesi tertentu tidak akan dapat dilakukan.

Berangkat dari gagasan inilah, pentingnya negara menetapkan kualifikasi standar advokat. Bukan hanya untuk membatasi orang-orang yang dapat diberi hak-hak tertentu dalam sistem dan proses peradilan, melainkan juga untuk melindungi masyarakat pengguna jasa hukum agar mendapatkan jasa yang memadai. Namun sesuai dengan ciri profesi yang mempunyai aturan otonom, batasan kualifikasi diatur oleh komunitas advokat sendiri melalui organisasi profesi. Pemerintah kualifikasi disahkan melalui sertifikasi. Disinilah negara dapat 
memberikan batasan mengenai pihak yang dapat disebut sebagai advokat berikut hak istimewa dalam sistem peradilan.

Kedudukan dan peranan lain yang mempunyai titik persinggungan dengan negara adalah menghormati institusi dan proses peradilan. Lembaga peradilan membutuhkan kewibawaan yang tinggi agar perintah-perintah atau putusannya dapat dihormati dan lebih mengikat. Advokat sebagai salah satu elemen peradilan dalam konteks integrated judiciary system harus ikut menjaga kewibawaan.

Sementara proses peradilan adalah sebuah proses publik, dimana setiap pelaku peradilan yang merepresentasikan kepentingan publik sesuai diferensiasi fungsinya saling beradu argumentasi hukum dan mengemukakan fakta-fakta untuk akhirnya menemukan keadilan. Agar proses peradilan bisa terlaksana dengan baik dan tujuannya bisa dicapai, setiap pihak wajib untuk saling menghargai fungsinya masing-masing, dan menghindarkan gangguan substansi terhadap pelaksanaan fungsi masingmasing dalam proses tersebut.

Pedoman normatif yang harus selalu dipegang advokat dalam menjalankan profesinya, terutama di bidang litigasi, adalah hukum acara. Sebagai perangkat hukum yang mengatur pelaksanaan fungsi setiap elemen peradilan agar ketentuanketentuan hukum material dapat ditegakkan. Ketaatan pada hukum acara layak ditempatkan sebagai salah satu kewajiban advokat sebab pelanggaran atas ketentuan hukum acara bisa berdampak luas bagi proses peradilan, dan bisa mendatangkan konsekuensi yuridis bagi pihak-pihak yang terkait dengan jalannya peradilan. Pelanggaran hukum acara juga potensial menganggu prinsip peradilan yang sederhana, murah dan cepat.

Dalam konteks pelaksanaan tugas advokat, ketaatan pada hukum acara akan lebih mudah diidentikan dengan perlindungan kepentingan hukum klien.
Dengan kuasa yang diberikan klien kepada advokat, pihak luar termasuk hakim, akan mengartikan setiap tindakan advokat pada proses peradilan sebagai tindakan klien, atau paling tidak dilakukan atas persetujuan klien. Pandangan sama juga berlaku terhadap kelalaian advokat. Pihak luar akan mengartikan kelalaian advokat sebagai kelalaian klien, atau ditimbulkan atas sepengetahuan klien.

Jika pelanggaran ketentuan hukum acara bagi advokat hanya merupakan kegagalan memenuhi standar profesinya, maka bagi klien kelalaian tersebut bisa mendatangkan kerugian substansial, yang seringkali menentukan nasib hidupnya.

Perlindungan kepentingan hukum klien, terdapat alasan lain yang menguatkan pentingnya taat prosedur dibebankan pada advokat. Alasan itu lebih melekat pada kedudukan dan peranan advokat sendiri, Jika keberadaan advokat dipahami sebagai kebutuhan sistem peradilan akan kedudukan dan peranan yang mandiri, yang mampu menjaga objektifitas dan keseimbangan proses peradilan bukan sebagai kebutuhan klien semata, maka kesalahan prosedur yang dilakukan advokat akan mengganggu proses peradilan secara sederhana.

\section{FAKTOR YANG MENGHAMBAT ADVOKAT DALAM MEWUJUDKAN KEDUDUKAN DAN PERANANNYA}

Agar bantuan hukum dapat bermanfaat bagi seluruh masyarakat, pelaksanaannya perlu dilakukan secara merata dengan penyaluran melalui berbagai institusi penegakan hukum yang ada seperti pengadilan, kejaksaan, organisasi advokat maupun organisasi masyarakat yang bergerak dibidang bantuan hukum.

Pada tataran normatif, diperlukan adanya pengaturan khusus yang sifatnya memfasilitasikan pelaksanaan bantuan hukum. Melihat kebutuhan akan keberadaan undang-undang ini dalam rangka menjamin hak masyarakat untuk mendapatkan keadilan maka sebaiknya 
pembuatan undang-undang bantuan hukum tidak diluar dari perspektif pelaksanaan bantuan hukum, melainkan dari kacamata masyarakat yang membutuhkannya sehingga diharapkan materi pengaturan yang tercakup didalamnya akan tepat pada sasaran yang dituju.

Pelaksanaan bantuan hukum kepada masyarakat tidak hanya sebatas memenuhi kebutuhan masyarakat akan pendampingan advokat dalam setiap proses hukum melainkan lebih jauh dari hal itu yaitu bagaimana menjadikan masyarakat mengerti hukum dan dapat mengkritisi produk hukum yang ada. Pengakuan negara harus diwujudkan bagi partisipasi masyarakat dalam pembentukan hukum. Hal yang terakhir ini dilaksanakan di antaranya dengan memberikan pendidikan hukum (civics education) kepada masyarakat.

Dengan kata lain jaminan terhadap bantuan hukum tidak an sich berkaitan dengan adanya undang-undang bantuan hukum, ketika yang dibicarakan adalah bantuan hukum dalam konteks struktural, maka perlu juga diperhatikan upaya pengembangan kapasitas masyarakat untuk mampu menyelesaikan sendiri permasalahan hukum yang dihadapinya lewat ketentuan yang memungkinkan penerapan Alternative Dispute Resolution (ADR). Perlu juga diperhatikan terhadap hak masyarakat untuk mengembangkan pengetahuannya dan sikap kritis terhadap setiap produk negara maupun yurisprudensi yang dihasilkan pengadilan dengan adanya ketentuan mengenai kebebasan mendapatkan informasi, serta berbagai ketentuan lain yang akan memberikan iklim kondusif bagi terselenggaranya bantuan hukum individual maupun struktural.

Berdasarkan kebutuhan masyarakat akan bantuan hukum sebagai hak dasar dalam hak asasi manusia untuk mendapatkan perlindungan dan persamaan kedudukan dihadapan hukum, maka peraturan bantuan hukum sebaiknya mencakup :

1. Jaminan terhadap masyarakat untuk mendapatkan akses ke peradilan formal dan untuk mendapatkan bantuan hukum yang merupakan wujud dari pelaksanaan bantuan hukum individual yang seyogianya dilakukan oleh advokat dan dijamin oleh penegak hukum lainnya pada setiap proses peradilan ;

2. Jaminan terhadap masyarakat untuk mendapatkan pendidikan hukum sebagai wujud dari pelaksanaan bantuan hukum struktural ;

3. Koordinasi antar unsur dalam melaksanakan bantuan hukum ;

4. Transparansi terhadap kebijakan hukum danperadilan ;

5. Pengaturan mengenai keterbukaan terhadap partisipasi masyarakat dalam mengkritisi produk hukum ;

6. Pengaturan terhadap partisipasi masyarakat dalam mengkritisi prosedur dan pelaksanaan penegakan hukum ;

7. Sanksi terhadap pelanggaran yang dilakukan. Pada tingkatan praktis, yang perlu dipikirkan adalah bagaimana sistem penyebaran bantuan hukum ini dan bagaimana pola pembiayaannya.

Namun sebelum berbicara lebih jauh mengenai hal tersebut perlu dibedakan pelaksanaan bantuan hukum individual dengan bantuan hukum struktural. Hal ini disebabkan adanya perbedaan karakteristik antara keduanya.

Bantuan hukum individual seperti dikatakan sebelumnya, lebih tertuju pada kegiatan pendampingan terhadap masyarakat dalam menyelesaikan masalahnya melalui proses hukum sehingga proses tersebut berjalan sebagaimana mestinya tanpa ada diskriminasi hukum. Hal ini mengakibatkan perlunya kualifikasi tertentu bagi pelaksana bantuan hukum individual, yaitu sarjana hukum yang menjadi advokat. 
Sementara bantuan hukum struktural kegiatannya lebih mengarah pada pemberdayaan dan penyadaran masyarakat akan hukum supaya mereka dapat memperjuangkan hak-haknya yang dilanggar dengan cara tertentu. Bantuan hukum struktural selama tidak bersentuhan langsung dengan proses peradilan dapat dilakukan oleh siapa saja tanpa harus memenuhi kualifikasi sarjana hukum atau advokat. Perbedaan lainnya terlihat pada target sasaran yang dituju, kalau pada bantuan hukum individual targetnya masyarakat secara individual sedangkan dalam bantuan hukum struktural targetnya masyarakat dalam arti kolektif.

Pada prakteknya dilapangan, kedua bentuk bantuan hukum ini dapat dilaksanakan secara sinergis dan saling mengisi satu sama lain. Kemudian agar pelaksanaan kedua jenis bantuan hukum tersebut dapat mencapai masyarakat hingga ke lapisan bawah yang berada di daerah-daerah, perlu dipikirkan cara mendirikan pos-pos bantuan hukum hingga ke struktur pemerintah daerah yang terkecil. Tujuannya memberikan perlindungan dan kesadaran hukum kepada masyarakat daerah mengingat mereka juga kerap menjadi korban ketidakadilan penguasa setempat. Pemberlakuan otonomi daerah memungkinkan penguasa daerah mengesampingkan hak-hak masyarakat guna memenuhi kepentingannya.

Pola pembiayaan bantuan hukum pro bono publico adalah termasuk salah satu faktor penghambat bagi advokat dalam melaksanakan kedudukan dan peranannya dalam masyarakat, pada awal tulisan disebutkan merupakan kewajiban negara sebagai konsekuensi jaminan negara terhadap hak-hak asasi warganya di bidang hukum. Salah satu bentuknya adalah dengan membantu pendanaan bantuan hukum. Dalam hal ini negara memberikan kontribusi dana operasional pada organisasi-organisasi masyarakat yang bergerak di bidang pelaksanaan bantuan hukum dan juga dengan cara membayar jasa pengacara yang ditunjuk oleh organisasi profesinya guna mendampingi klien dalam rangka pelaksanaan bantuan hukum.

Kelangsungan pelaksanaan bantuan hukum tidak lepas dari peran advokat sebagai realisasi dari tanggung jawab dan kepedulian sosialnya terhadap masyarakat. Perlu adanya dukungan yang kuat dari advokat baik berupa tenaga maupun dana untuk pelaksanaan bantuan hukum. Dari segi tenaga, pada advokat tersebut dapat turut secara aktif ke lapangan melakukan kegiatan bantuan hukum melalui cara- cara yang telah dijelaskan sebelumnya. Bagi advokat yang tidak dapat meluangkan waktunya guna melaksanakan bantuan hukum, bisa memberikan dukungan berupa sumbangan dana dalam jumlah minimum tertentu. Sumbangan dana tersebut dikumpulkan melalui organisasi advokat untuk kemudian disalurkan kepada lembaga-lembaga bantuan hukum yang memang telah memenuhi persyaratan untuk mendapatkannya. Sumbangan itu di satu sisi dapat menjadi alternatif pemecahan sumber dana bagi pelaksanaan bantuan hukum, tanpa harus bergantung dengan negara ataupun lembaga-lembaga donor asing, dan sisi lain turut memberdayakan pelaksanaannya. Kemudian sebagai pertanggung-jawaban dari penerimaan dana tersebut, lembagalembaga bantuan hukum yang menerimanya wajib memberikan laporan secara berkala kepada negara dalam hal ini Departemen Kehakiman dan juga kepada organisasi advokat mengenai kegiatan bantuan hukum yang dilakukannya serta dibuka peluang masyarakat untuk mendapatkannya.

\section{KESIMPULAN}

Advokat mempunyai kedudukan dan peranan yang sangat penting sebagai salah satu unsur dari Catur Wangsa Penengak Hukum, karena status advokat bebas dan mandiri yang dijamin oleh hukum dan peraturan perundang-undangan, 
pembelaan bagi semua orang termasuk masyarakat merupakan wujud penghayatan advokat terhadap prinsip persamaan kedudukan di hadapan hukum sekaligus perwujudan hak yang dimiliki semua orang yaitu hak untuk didampingi advokat, yang dilatar belakangi oleh tanggung jawab moral kemanusiaan dan kondisi ekonomi klien; Demi kepentingan hukum dan tuntutan profesi yang memiliki aspek sosial, yaitu setiap orang yang terlibat perkara berhak dan terjamin tersedianya akses untuk mendapatkan bantuan hukum.

Faktor yang menghambat advokat dalam mewujudkan kedudukan dan peranannya yaitu Pada tataran normatif, belum adanya pengaturan tentang bantuan hukum secara khusus yang mengatur seluruh ruang lingkup tentang pemberian bantuan hukum, peraturan yang ada hanya bersifat general/umum yang diatur secara terpisah atau sporadis sehingga mengakibatkan adakalanya advokat dalam memberikan bantuan hukum tidak secara sungguh-sungguh, oleh karena tidak ada sanksi yang dapat diterapkan apabila seorang advokat dalam memberikan bantuan hukum ternyata tidak benar-benar memberikan bantuan hukum kepada kliennya.

Sebaiknya kedudukan dan peranan advokat dalam menjalankan profesinya senantiasa dilakukan pengawasan secara intensif oleh lembaga advokat, pengawasan tersebut dilakukan guna meningkatkan kualitas para advokat secara maksimal khususnya dalam memberikan bantuan hukum kepada seluruh masyarakat. dan kontribusi ilmiah dalam pengembangan ilmu pengetahuan dan teknologi.

\section{SARAN}

Berdasarkan kebutuhan masyarakat akan bantuan hukum sebagai hak dasar dalam hak asasi manusia yang juga merupakan hak konstitusional untuk mendapatkan perlindungan dan persamaan kedudukan dihadapan hukum, maka diperlukan peraturan khusus yang sifatnya memfasilitasikan pelaksanaan bantuan hukum yang isinya sebaiknya mencakup:

1. Jaminan terhadap masyarakat untuk mendapatkan akses ke peradilan formal dan untuk mendapatkan bantuan hukum yang merupakan wujud dari pelaksanaan bantuan hukum individual yang seyogianya dilakukan oleh advokat dan dijamin oleh penegak hukum lainnya pada setiap proses peradilan;

2. Jaminan terhadap masyarakat untuk mendapatkan pendidikan hukum sebagai wujud dari pelaksanaan bantuan hukum struktural;

3. Koordinasi antar unsur dalam melaksanakan bantuan hukum dan transparansi terhadap kebijakan hukum dan peradilan;

4. Pengaturan mengenai keterbukaan terhadap partisipasi masyarakat dalam mengritisi produk hukum, prosedur dan pelaksanaan penegakan hukum.

\section{UCAPAN TERIMA KASIH}

\section{DAFTAR PUSTAKA}

Chaidir, Ellydar. 2007. "Negara Hukum, Demokrasi dan Konstalasi Ketatanegaraan Indonesia". Yogyakarta: Kreasi Total Media, Yogyakarta, 2007.

Djaali. H, dkk. 2003. "Hak Asasi Manusia (Suatu Tinjauan Teoritis dan Aplikasi)". Jakarta: CV. Restu Agung. 
Hasibuan, Otto. "Advokat Yang Tidak Memberikan Bantuan Hukum Akan Diberikan Sanksi". Pidato da- lam Deklarasi Peradi, Jakarta, tanggal 23 Desember 2004.

Hestu, Handoyo Cipto. 2003. "Hukum Tata Negara, Kewarganegaraan dan Hak Asasi Manusia". Yogyakar- ta: Universitas Atmajaya.

Nasution, Adnan Buyung. 1982. "Bantuan Hukum di Indonesia". Jakarta: LP3ES.

Pandu, Yudha. 2005. "Klien dan Advokat Dalam Praktek". Jakarta: PT. Abadi.

Rosyada, Dede, dkk. 2000. "Pendidikan Kewargaan (Civic Education) : Demokrasi Hak Asasi Manusia dan Masyarakat Madani". Jakarta: ICCE UIN Syarif Hidayatullah Prenada Media.

Saragih, Bintan R. 2006. "Perubahan, Penggantian dan Penetapan Undang-Undang Dasar di Indonesia”. Bandung: CV. Utomo.

Sembiring, Sentosa. 2006. "Himpunan Perundang-Undangan Republik Indonesia Tentang Hak Asasi Manu- sia”. Bandung: CV. Nuansa Aulia.

Undang-Undang Nomor 18 Tahun 2003 tentang Advokat, Citra Umbara, Bandung, 2003.

Winarta, Frans H. "Dasar Konstitusional Bantuan Hukum", tersedia di http://jodisantoso.blogspot.com June 16, 2007. 